\title{
67. ESTIMATING IN-SITU STRESS FIELD FROM BASALTIC ROCK CORE SAMPLES OF HOLE 794C, YAMATO BASIN, JAPAN SEA ${ }^{1}$
}

\author{
Kensaku Tamaki² and Kiyohiko Yamamoto ${ }^{3}$
}

\begin{abstract}
We carried out an experiment to estimate in-situ stresses at ODP Hole 794C (water depth: $2809 \mathrm{~m}$ ) from the basaltic core samples by deformation rate analysis (DRA). Site 794 is located at the northern end of the Yamato Basin and $70 \mathrm{~km}$ west of the eastern Japan Sea intraplate or interplate convergent zone. Stress previously applied to a rock specimen is identified in the inelastic strain behavior of the specimen under uniaxial compression by the method used. Natural remanent magnetization of the sample was also measured to get a reference for the orientation of the horizontal stresses. The vertical, maximum, and minimum horizontal in-situ stresses estimated at a depth of 582 mbsf are $36.4,43.1$, and $31.2 \mathrm{MPa}$, respectively. The average of the largest and the least horizontal stresses is nearly equal in value to the vertical stress. This suggests that the site is in the stress field of the strike slip regime at the depth, while the stress field of the reverse fault regime has been estimated from the focal mechanism solutions of the earthquakes whose hypocenters are located near or on the convergent boundary. The directions of the largest and the least horizontal stress are estimated to be northeast-southwest and in northwest-southeast, respectively, in taking account of rotation tectonics of the Japan Sea since its formation. The directions of the largest and the least horizontal stresses are opposite to those determined from the earthquakes. These discrepancies of our results with those from earthquakes may be due mainly to the fact that the site is not in the convergent zone.
\end{abstract}

\section{INTRODUCTION}

The convergent plate margin is a zone where a radical variation of the stress field is expected through the forearc to the backarc region. The active convergent tectonics of the eastern margin of the Japan Sea have been well documented with abundant data for the submarine topography, earthquake mechanism solutions (Fukao and Furumoto, 1975; Yamazaki et al., 1985), and active geological structure on land and undersea (Tamaki and Honza, 1985; Awata and Kakimi, 1985). Ocean Drilling Program (ODP) drilling results at Site 796 demonstrated that the Okushiri Ridge is crust heaved up from the deep-sea basin by convergent tectonics and that the upheaval started at $1.8 \mathrm{Ma}$ (Tamaki, Pisciotto, Allan, et al., 1990). Currently, the eastern margin of the Japan Sea represents an obvious convergent zone with the intermittent occurrence of large earthquakes (Fukao and Furumoto, 1975; Tamaki and Honza, 1985). The trend of the compressional axis is generally east-west according to earthquake mechanism solutions and the distribution of active thrust faults. Measurements of the in-situ stress field in this situation will present indispensable information for the quantitative analyses of the convergent tectonics. As there is no information about the in-situ stress state in the Japan Sea, our experiment may provide the first specific information for the in-situ stress field in this region.

Collecting in-situ stress information from the seabottom crust of the Japan Sea was one of the major objectives of Leg 127. The packer/hydrofracturing experiment and borehole televiewer (BHTV) were originally planned to be conducted during the cruise to measure the in-situ stress state in the boreholes. However, because of extremely unstable hole conditions all of the attempted experiments were abandoned or unsuccessful. The experiment presented here, utilizing the stress memory of the rock samples, is our only remaining option to get or estimate in-situ stress field of the Japan Sea floor using the ODP data.

'Tamaki, K., Suyehiro, K., Allan, J., McWilliams, M., et al., 1992. Proc. ODP, Sci Results, 127/128, Pt. 2: College Station, TX (Ocean Drilling Program).

${ }^{2}$ Ocean Research Institute, University of Tokyo, Minamidai, Nakano, Tokyo 164, Japan.

${ }^{3}$ Faculty of Science, Tohoku University, Sendai 980, Japan.
Many methods for determining the state of stress in the crust have been developed in order to understand the actual stress conditions. Observation of borehole breakouts using the BHTV (Newmark et al., 1983; Zoback et al., 1985) and the packer/hydrofracturing method (McGarr and Gay, 1978) are frequently used by the Ocean Drilling Program. Newmark et al. (1983) observed breakouts in Deep Sea Drilling Project (DSDP) Hole 504B with BHTV to determine the direction of the horizontal principal stresses. The method based on borehole breakouts originally lacked information for addressing the magnitude of stress; however, it is now sufficiently sophisticated to detect the magnitude of stress through the detailed analysis of breakout shape (Zheng et al., 1989). The other commonly used borehole method is the packer/hydrofracturing experiment, which is used to measure both the magnitude and direction of the stress field. The packer/hydrofracturing method, however, is rarely successful because the method requires clean and stable hole conditions and also needs a long operation time. This was the case for Leg 127.

The other approach for estimating in-situ stress state is to use core samples from the borehole. Tamaki et al. (1991) were the first to try to estimate the in-situ stress state from deep-sea rock core samples. They applied the deformation rate analysis (DRA) method that was developed by Yamamoto et al. $(1983,1990)$ and applied to the rock core samples of the Ninetyeast Ridge in the Indian Ocean by Tamaki et al. (1991). As the orientation are basically unknown in the deep-sea drilling cores, they used paleomagnetic north as a reference of the orientation of stress field with a consideration of the amount of plate rotation since the volcanic rocks were originally magnetized.

We applied the DRA to basaltic rock samples from Hole 794C. Site 794 is located at the northern end of the Yamato Basin in the Japan Sea at $40^{\circ} 11.40^{\prime} \mathrm{N}, 138^{\circ} 13.86^{\prime} \mathrm{E}$ (Fig. 1). Hole $794 \mathrm{C}$ penetrated $111 \mathrm{~m}$ of basaltic rocks beneath $543 \mathrm{~m}$ of mostly siliceous Neogene sediments (Tamaki, Pisciotto, Allan, et al., 1990) in a water depth of $2809 \mathrm{~m}$. The site is $70 \mathrm{~km}$ west of the epicenter of the 1983 Central Japan Sea earthquake $(M=7.7)$, which occurred on a convergent boundary between the Japan Sea and the Japanese Islands as a thrust-type earthquake. We use the declination of natural remanent magnetization (NRM) as a reference for the orientation of the estimated in-situ horizontal stresses. The NRM-determined north, however, may have shifted to some extent since the basaltic rocks were erupted. We have to take into account this effect in evaluating the orientation of the stress field. 


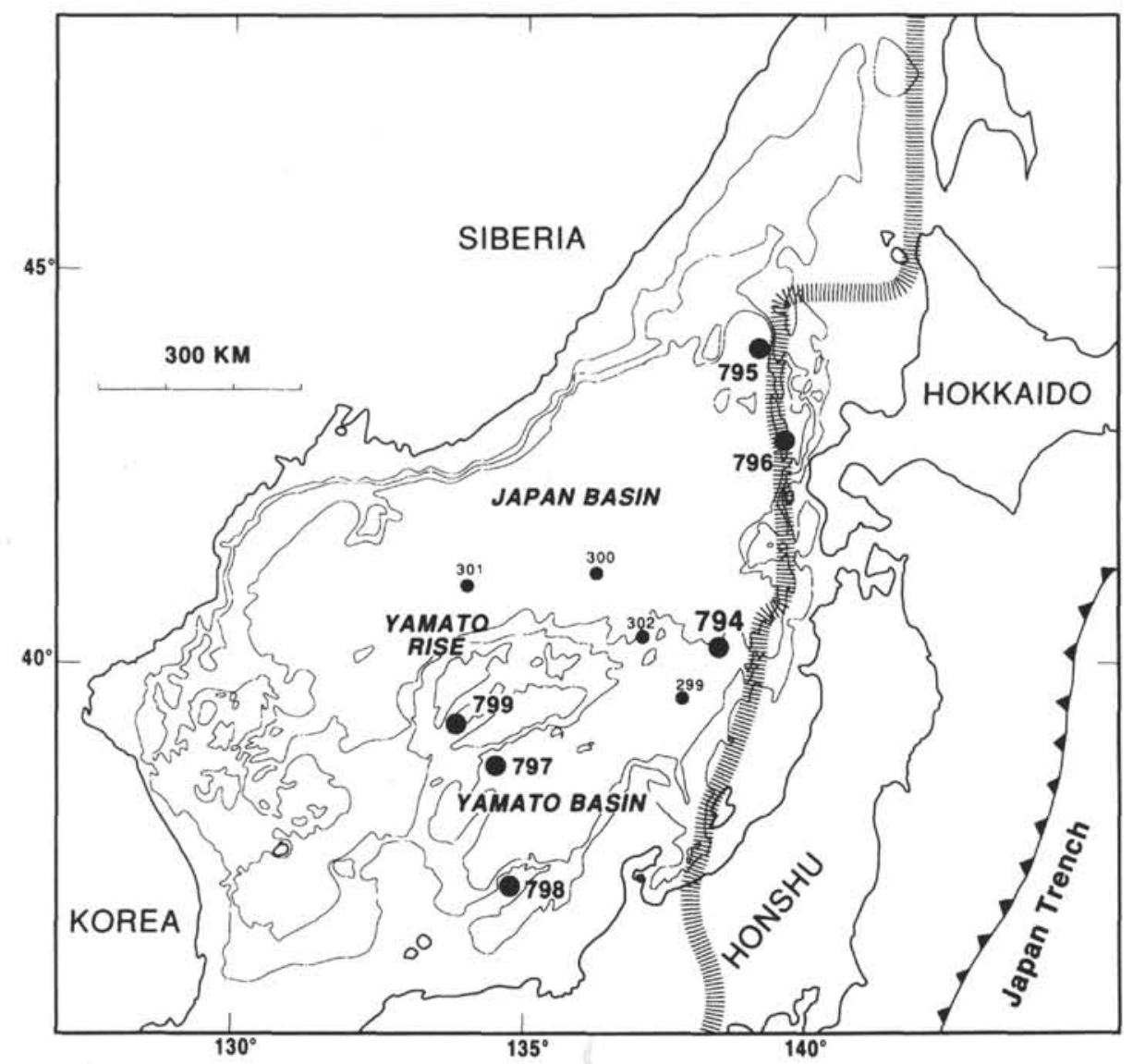

Figure 1. Location of Site 794 at the northern end of the Yamato Basin and other ODP and DSDP sites in the Japan Sea. The ruled line shows the convergent boundary between the Japan Sea and Japanese Islands.

\section{DEFORMATION RATE ANALYSIS}

The DRA method uses the behavior of inelastic strain of the specimen under uniaxial compression to determine the stress previously applied to a specimen. This method is similar to the acoustic emission (AE) method (e.g., Kanagawa et al., 1977) in that both of them utilize the inelastic properties of rocks under compression. Yamamoto et al. (1990) experimentally demonstrated that the previous stress can be obtained from a change in the gradient of stressstrain relation under cyclic uniaxial compression tests for a specimen, and they named the procedure the deformation rate analysis (DRA).

The gradient changes were not commonly determined in the stress-strain relations obtained by conventional techniques in the case of small previous stresses, because the change is buried in the larger nonlinearity of the stress-strain relation resulting from other sources, for example, crack or pore closure (Walsh, 1965; Simmons et al., 1974; Siegfried and Simmons, 1978). Yamamoto et al. (1990) performed cyclic uniaxial loading tests and measured the difference strain values during loading between two cycles as a function of the applied stress:

$$
\Delta \varepsilon_{i, j}=\varepsilon_{j}(\sigma)-\varepsilon_{i}(\sigma) ; j>i,
$$

where $\varepsilon_{\mathrm{k}}$ is the strain in the $\mathrm{k}^{\text {th }}$ loading and $\sigma$ the applied stress. This function, called the strained difference function, represents mainly the difference of inelastic strain between the two cycles. More microcracks are well known to be generated during the first loading than the second. We may expect that the relation of inelastic strain to applied stress is linearized in the second cycle more than in the first cycle (Yamamoto et al., 1990). Thus, the expected gradient change should be easily discriminated in the strain difference functions rather than in the ordinary stress-strain relations.

An increase in axial stress has been known to monotonously increase inelastic strain of a specimen under uniaxial compression and to lead the specimen to its fracturing through the dilatancy. In addition to the inelastic strain of this mode of behavior, we assume the other mode of inelastic strain as follows, that is, rocks have been being subjected to in-situ stresses at depths for a long time. Thus, it may be reasonable to provide that stress concentration in the stress field in rocks has faded, or the least nonuniform state has been attained for the stress field under in-situ stress condition. If stresses of compression are applied to a specimen from a depth with a relatively high stress rate as much as taken for the loading tests, the stress field in the specimen may be more nonuniform at any applied stresses which have not identical values to those of in-situ stresses, because the constituent minerals of rocks with different elastic moduli are strained with different magnitudes from one another by the applied stresses. We may expect thus that the inelastic strain begins to increase at the applied stress nearly equal in value to the in-situ stress, when the applied stress is increased. For convenience, we call the inelastic strain of the former mode of behavior the first mode inelastic strain and that of the latter the second mode. Thus, when the disturbance due to the first mode strain to the strain difference functions is small, in-situ stresses should be estimated by discriminating the bending point in the strain difference functions.

Although the above idea has not been established as yet, Yamamoto et al. $(1983,1989,1990)$ found that the strain difference function bends at the applied stress close in value to that of a normal component of in-situ stress along the loading axis by applying DRA to the specimens from core boring samples. They concluded from the result 
that DRA is practically applicable to the estimation of in-situ stresses. Their studies are summarized briefly in our previous paper (Tamaki et al., 1991).

\section{STRESS MEASUREMENT PROCEDURE}

We collected basaltic sample cubes $20 \mathrm{~mm}^{3}$ in size from depths of 561,582 , and $602 \mathrm{~m}$ below seafloor (mbsf) from Hole $794 \mathrm{C}$ in a water depth of about $2809 \mathrm{~m}$ (Fig. 2). Samples 127-794C-1R-1, 95-105 cm, 127-794C-4R-1, 29-38 cm, and 127-794C-7R-1, 87-96 cm, each comprise four cubes, collected in a continuous single piece. The samples obtained from Core 127-794C-7R were too brittle for this experiment and measurement of the samples from Core $127-794 \mathrm{C}-7 \mathrm{R}$ was abandoned. Remanent magnetization was measured for two cubes from each depths prior to conducting the stress measurements. The wet-bulk densities of the samples are between 2.47 and 2.71 $\mathrm{g} / \mathrm{cm}^{3}$, and the $P$-wave velocities are between 4291 and $5186 \mathrm{~m} / \mathrm{s}$ (Tamaki, Pisciotto, Allan, et al., 1990). We weighed the specimens used for this experiment in air and in water after keeping them in water for about 20 days to obtain the wet-bulk densities. The specimens were dried at about $60^{\circ} \mathrm{C}$ for about $48 \mathrm{hr}$ in a vacuum vessel to obtain the dry-bulk densities. The densities are listed in Table 1 together with the apparent porosities and the grain densities. The apparent porosities and grain densities are calculated from the dry- and wet-bulk densities. We could not measure Core 127-794C-1R because the specimen broke in the water

We sawed one to four specimens from each cubic sample for obtaining stress measurement. Each specimen is a rectangular prism, about $10 \mathrm{~mm} \times 10 \mathrm{~mm} \times 20 \mathrm{~mm}$ in size. Before the measurement of previous stress, Young's modulus was measured (Table 2). The samples of Core 127-794C-7R were found to be exceptionally weak.

The previous stress was measured in the direction of the longer axis. The specimens for the measurement of horizontal previous stress were sawed to have four orientations of $0^{\circ}, 45^{\circ}, 90^{\circ}$, and $135^{\circ}$ against the split surface so that we could estimate the horizontal maximum and minimum stress directions by least-squares estimation. The loading system and strain gauge placement are schematically illustrated in Figure 3. In order to measure the previously applied stress, uniaxial compressional loading was cycled 5 or 6 times to each specimen (Fig. 4). The loading was performed at a constant stress rate by a servocontrolled apparatus. The peak value of the applied stress was set constant for any cycles during each measurement. The peak value ranged between 40 and $55 \mathrm{MPa}$. Loading rates were between 6.7 and $8.3 \mathrm{MPa} / \mathrm{min}$. Unloading rates were twice as fast as the corresponding loading rate.

Axial strains reach to about $2 \times 10^{3}$ at $40 \mathrm{MPa}$ in applied axial stress for the samples of Core 127-794C-1R, as calculated from the apparent Young's moduli in Table 2. Although we have not measured the compressional strengths of the specimens, they did not seem to be much larger than $50 \mathrm{MPa}$, because we observed in the Young's modulus measurements that the axial strain continued to increase near the peak applied stress of $45 \mathrm{MPa}$ even after the unloading had started. For this reason, we had to set the peak stresses at relatively small values compared with those of the in-situ stress to be estimated in order to keep the damage of the specimens as small as possible. The strengths of the samples of Core 127-794C-4R are inferred to be not much larger than $70 \mathrm{MPa}$ from their apparent Young's moduli in Table 2. According to Brace et al. (1966), the dilatancy becomes remarkable at the applied stress near 0.4 as much as the strength of the specimen, which corresponds to about 20 and $30 \mathrm{MPa}$ for the samples of Cores 127-794C-1R and 127-794C-4R, respectively. This suggests that the nonlinearity of the strain difference functions may be remarkable at the applied stresses larger than 20 or $30 \mathrm{MPa}$, because inelastic strain in the dilatant stage increases with an increase in the loading cycles (Zoback and Byerlee, 1975).

We write the strain difference function $\Delta \varepsilon_{i, j}(\sigma)$ defined by equation (1) as $(\mathrm{i}, \mathrm{j})$ for simplicity. Contraction and compression are

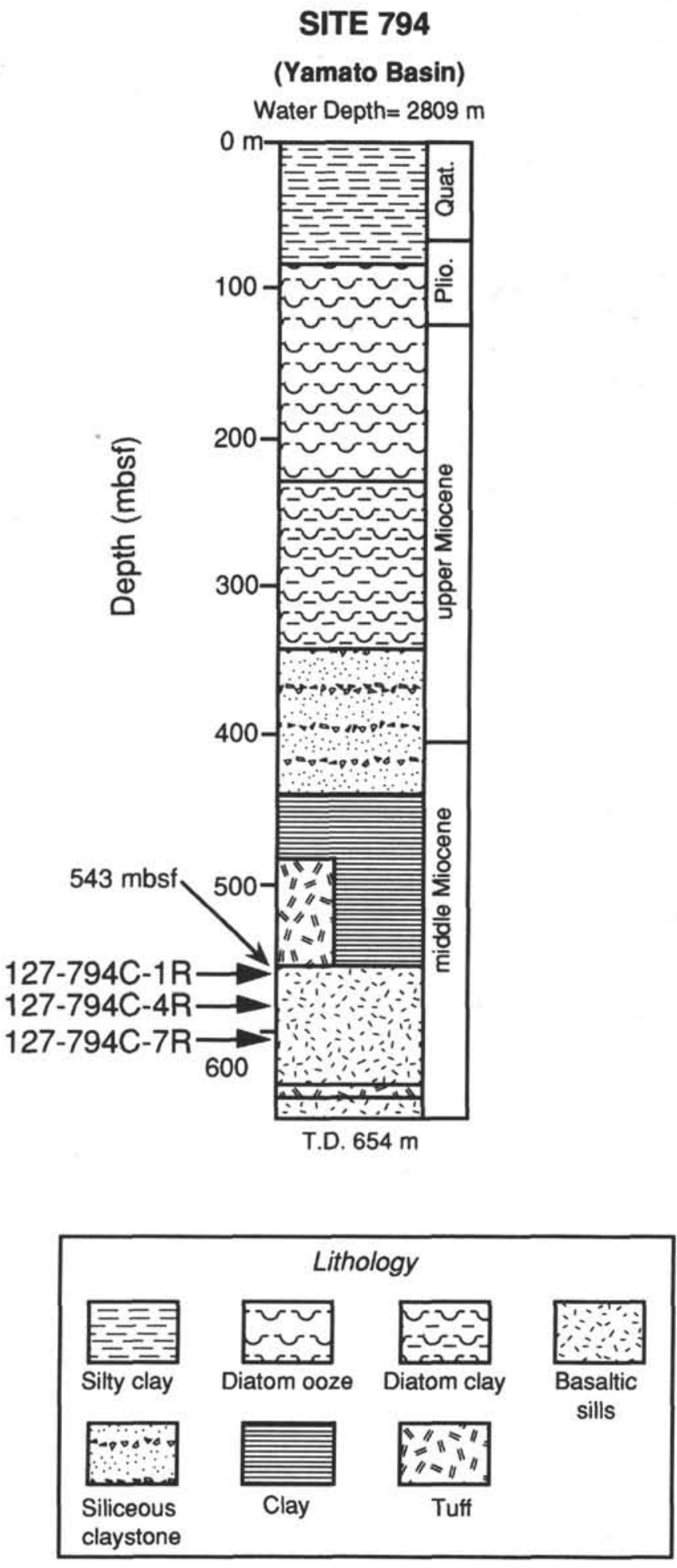

Figure 2. Sample depths shown with the lithologic core summary for Hole 794C.

defined as positive. A negative gradient change of the function indicates that the increasing rate of inelastic strain with increasing stress is larger in the $\mathrm{i}^{\text {th }}$ loading than in the $\mathrm{j}^{\text {th }}$ loading. Thus, the increasing rate of the inelastic strain in the $i^{\text {th }}$ cycle should be observed as a negative gradient change of the function (i,j). In order to exaggerate the inelastic strain and measure the strain difference with a maximum resolution, we took the difference between the strain measured by strain gauges and that obtained from the measured stress multiplied 
Table 1. Physical properties of the measured cores.

\begin{tabular}{ccccc}
\hline $\begin{array}{c}\text { Core, section, } \\
\text { interval }(\mathrm{cm})\end{array}$ & $\begin{array}{c}\text { Wet-bulk } \\
\text { density } \\
\left(\mathrm{g} / \mathrm{cm}^{3}\right)\end{array}$ & $\begin{array}{c}\text { Dry-bulk } \\
\text { density } \\
\left(\mathrm{g} / \mathrm{cm}^{3}\right)\end{array}$ & $\begin{array}{c}\text { Apparent grain } \\
\text { density } \\
\left(\mathrm{g} / \mathrm{cm}^{3}\right)\end{array}$ & $\begin{array}{c}\text { Apparent } \\
\text { porosity } \\
(\%)\end{array}$ \\
\hline $127-794 \mathrm{C}-4 \mathrm{R}-1,35-37$ & 2.66 & 2.55 & 2.86 & 10.6 \\
$127-794 \mathrm{C}-7 \mathrm{R}-1,94-96$ & 2.40 & 2.17 & 2.85 & 22. \\
\hline
\end{tabular}

Table 2. Young's modulus of measured samples.

\begin{tabular}{ccccc}
\hline & & \multicolumn{2}{c}{ Apparent Young's modulus } \\
\cline { 3 - 5 } $\begin{array}{c}\text { Core, section, } \\
\text { interval (cm) }\end{array}$ & $\begin{array}{c}\text { Number } \\
\text { of samples }\end{array}$ & $0-1000 \mathrm{ppm}$ & $0-2000 \mathrm{ppm}$ \\
\hline $127-794 \mathrm{C}-1 \mathrm{R}-1,99-107$ & 8 & $23.5 \pm 1.3$ & \\
& 8 & & $19.3 \pm 1.59$ \\
$127-794 \mathrm{C}-4 \mathrm{R}-1,29-40$ & 10 & $32.7 \pm 1.9$ & 28.0 \\
& 1 & & $9.2 \pm 0.8$ & \\
$127-794 \mathrm{C}-7 \mathrm{R}-1,90-92,94-96$ & 4 & & $8.0 \pm 0.35$ \\
\hline
\end{tabular}

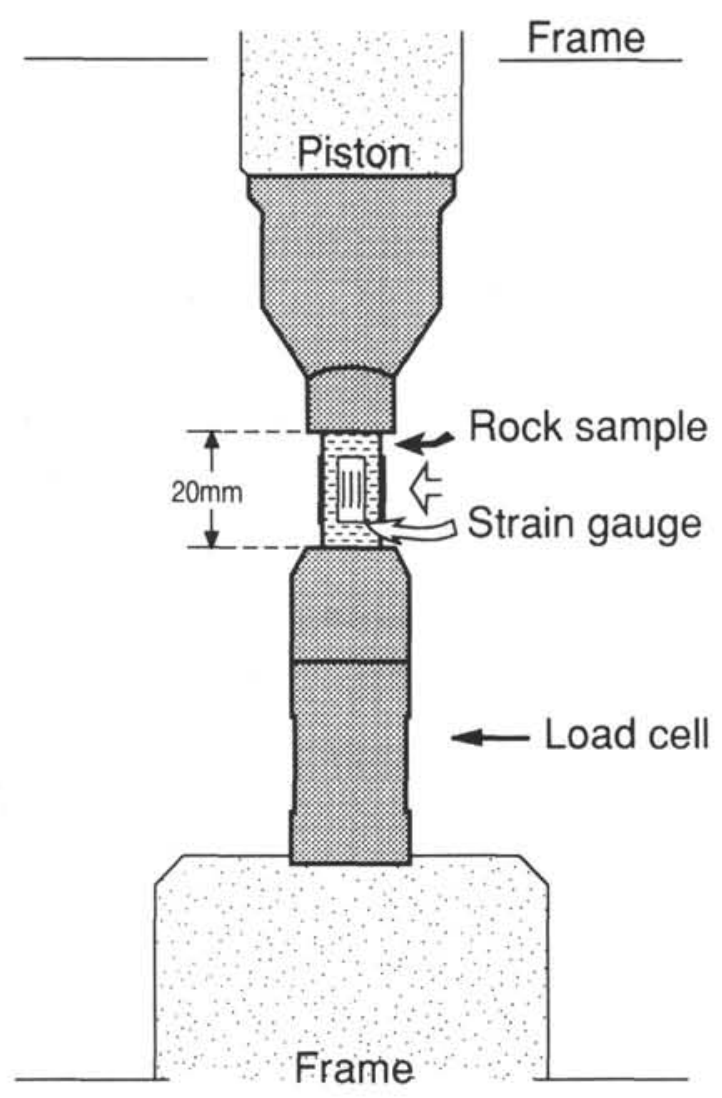

Figure 3. Sample loading system. Four strain gauges are pasted near the center of the free surfaces of the sample.

by a constant which is approximated to the Young's modulus and amplified the difference about 5 times with an amplifier with accuracy of about $2 \%$. We call this difference the reduced strain. This procedure enables us to read the strain change less than $0.1 \mathrm{ppm}$ in the case of hard rocks (Yamamoto et al., 1990). We may notice that the procedure is effective also to depressing the high-frequency changes in the reduced strain, because the strain caused by the high-frequency stress due to the servocontrolled apparatus is more or less elastic. The stress-strain curve and the reduced stress-strain curve obtained from the vertical specimen of Sample 127-794C-1R-1, 105-107 cm, are shown in Figure 4. This measurement was performed about $20 \mathrm{~min}$ after the Young's modulus measurement.

\section{RESULTS OF GEOMAGNETIC MEASUREMENTS}

Remanent magnetization was measured on Schonstedt spinner magnetometers (SSM-1A and DSM-2), and alternating field (AF) demagnetization was carried out on a Schonstedt two-axis tumbler demagnetizer (GSD-5) with a maximum AF field of $500 \mathrm{mT}$ for Samples 127-794C-1R-1, 95-97 cm, 127-794C-1R-1, 102-104 cm, $127-794 \mathrm{C}-4 \mathrm{R}-1,29-31 \mathrm{~cm}$, and $127-794 \mathrm{C}-4 \mathrm{R}-1,32-34 \mathrm{~cm}$. Because samples from the same section have an identical split surface, their paleomagnetic orientations should be the same against the split-core surface.

In order to determine the horizontal direction of the split surface, the optimal declination of each sample was examined by the step demagnetization (Fig. 5). Paleomagnetic north of Samples 127-794C$1 \mathrm{R}-1,95-97 \mathrm{~cm}$, and $127-794 \mathrm{C}-1 \mathrm{R}-1,102-104 \mathrm{~cm}$, is estimated to be shifted $2^{\circ}$ clockwise from the direction normal to the split surface when the core samples are observed "upward." Paleomagnetic north of Samples 127-794C-4R-1, 29-31 cm, and 127-794C-4R-1, 32-34 $\mathrm{cm}$, is estimated to be shifted $183^{\circ}$ clockwise from the direction normal to the split surface as well.

We originally expected to estimate the present magnetic north of the samples by discriminating secondary magnetization. If the orientations of secondary magnetization of several cubic samples show an identical shift from the paleomagnetic north, the secondary magnetization was caused by the present magnetic field in situ. However, the directions of secondary magnetization of the basaltic samples at Site 794 are rather random (Ingle, Suyehiro, von Breymann, et al., 1990), and we could not obtain the orientation of present north for the samples. The paleomagnetic north of the samples was the only information on orientation available to evaluate the direction of the stress field.

\section{RESULTS OF STRESS MEASUREMENTS}

\section{Vertical Stresses}

Estimation of the in-situ vertical stresses from the measured specimens provides us an important opportunity to verify our method because we can independently estimate the present in-situ vertical stress by calculating overburden pressure from the core lithology and physical properties. The vertical stresses were measured on the paired specimens S-1 and S-2 of Sample 127-794C-4R-1, 35-37 cm. The measurement consisting of 5 cycles of loading were performed on the specimens S-1 and S-2. The measurement was repeated twice on S-1. Figure 6 shows the strain difference functions $\Delta \varepsilon_{i, j}(\sigma)$, or $(i, j)$ for the vertical specimens $\mathrm{S}-1$ and $\mathrm{S}-2$ which have the relatively clear bending points at the axial stresses more than $30 \mathrm{MPa}$. This value is less than the value of about $34 \mathrm{MPa}$ estimated above as the smallest one of overburden pressure. This is considered to be caused by the pore pressure effect, and will be explained in the next section.

The traces of $(\mathrm{i}, \mathrm{j})$ show significant nonlinear behavior. This may be caused by the small strengths of the specimens as described before. Without information about the in-situ stress at the sample depth, we cannot uniquely identify the previous stress from these data because of the large nonlinearity. However, we can assume that the overburden pressures are more than the water pressure of about $34 \mathrm{MPa}$ at a depth of $3392 \mathrm{~m}$ below the sea surface. With this information and on the condition that the vertical previous stresses of the specimens at the same depth should be the same, we picked from each strain difference function one of the applied stresses at which the gradient change of $\Delta \varepsilon_{i, j}(\sigma)$ is relatively large and read its magnitude as that of the previous stress (marked with arrows in Fig. 6). The average of the stress magnitude thus read is $32.9 \pm 1.3 \mathrm{MPa}$.

We calculated an overburden pressure of $37.0 \mathrm{MPa}$ from the water column of $2809 \mathrm{~m}$ and density data measured on board for $0-376$ mbsf from Hole 794A, 376-560 mbsf from Hole 794B, and $560 \mathrm{mbsf}$ 

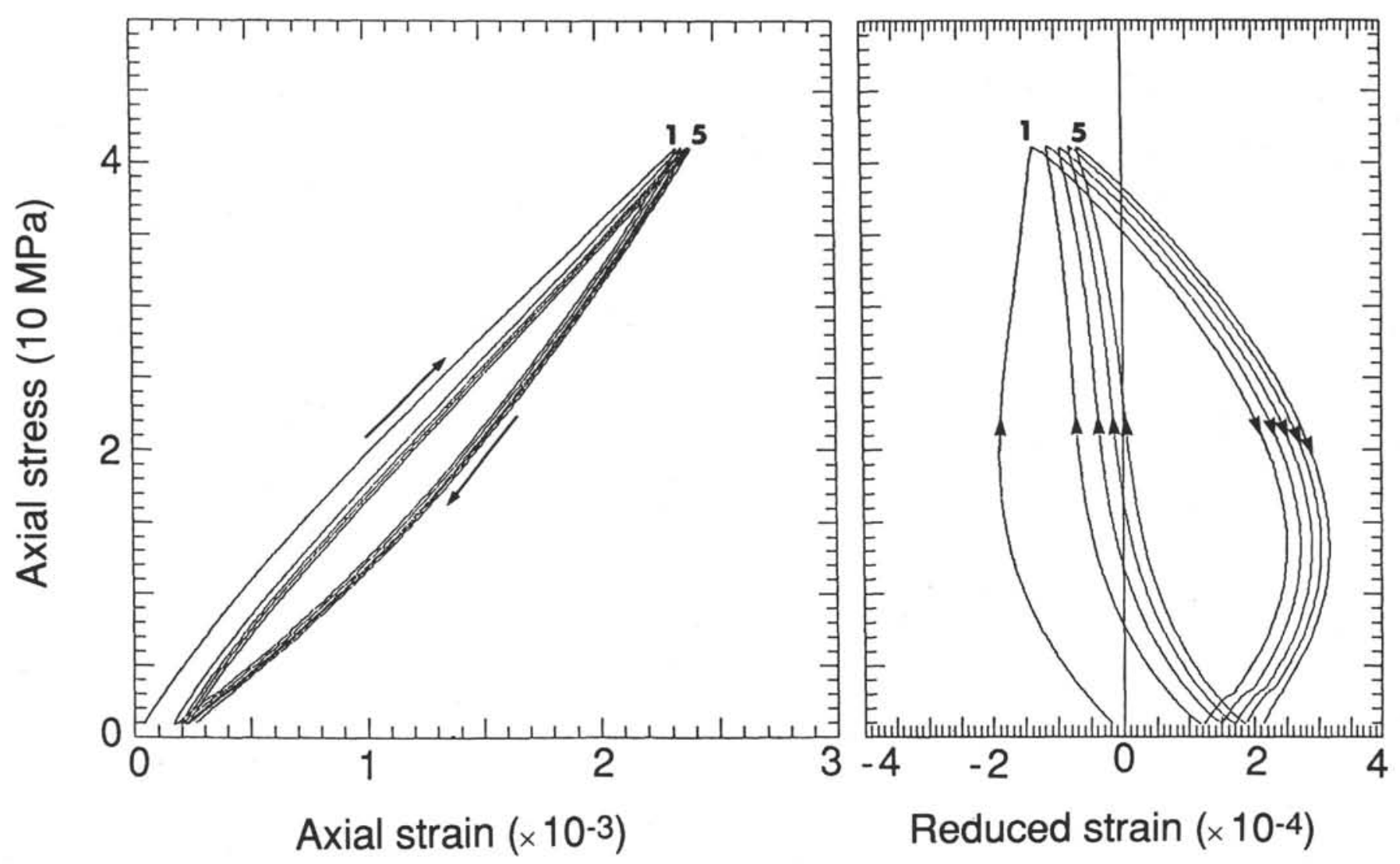

Figure 4. Stress-strain curves and reduced stress-strain curves for the vertical specimen, S-1, from Core 127-794C-1R. Numerals 1 through 5 indicate the cycle numbers of loading and unloading. Cycle numbers 2 through 4 in the stress-strain curves are omitted for clarity. Time flows are shown by the arrows.

and deeper from Hole 794C. As suggested by Tamaki et al. (1991), we took into account the effect of pore pressure effect to estimate in-situ stress magnitudes. The average stress in rocks, $\sigma^{\mathrm{av}}{ }_{\mathrm{ij}}$, that is, the in-situ stress, may be expressed as

$$
\sigma^{\mathrm{av}}{ }_{\mathrm{ij}}=\phi_{\mathrm{sl}} \cdot \sigma_{\mathrm{ij}}^{\mathrm{sl}}+\phi_{\mathrm{pr}} \cdot \sigma^{\mathrm{pr}} \cdot \delta_{\mathrm{ij}}
$$

where $\phi_{\mathrm{sl}}$ and $\phi_{\mathrm{pr}}$ are the volume fraction of the solid part and the liquid part, respectively, $\sigma^{\mathrm{sl}}$ ii and $\sigma^{\mathrm{pr}}$ are a component of the average stress in the solid part, and the pore pressure, $\delta_{\mathrm{ij}}$ is Kronecker's delta (Tamaki et al., 1991). Because pore pressure is absent during the stress measurement experiment, the stress measured should correspond to the first term of the right-hand side of equation (2). Assuming that all pores are interconnected with one another, the pore pressure is nearly equal in value to the water pressure at the depth. We can calculate a pore-pressure effect of $3.5 \mathrm{MPa}$ from the water depth $2809 \mathrm{~m}$, the depth below seafloor of $582 \mathrm{~m}$ of Section 127-794C-4R-1, and the porosity of Sample 127-794C-4R-1, 35-37 cm. After correction of pore-pressure effect by adding $3.5 \mathrm{MPa}$ to the measured value of 32.9 $\mathrm{MPa}$, we get the estimated in-situ stress of $36.4 \mathrm{MPa}$.

The calculated overburden pressure of $37.0 \mathrm{MPa}$ is comparable with the estimated in-situ vertical stress of $36.4 \mathrm{MPa}$. This fairly close coincidence allows us to insist that our current experiment is valid in terms of estimation of magnitudes of in-situ stress field and that the estimated in-situ stress is close to the present in-situ stress rather than the fossil stress at some time ago in the geological time.

\section{Horizontal Stresses}

The azimuthal distribution of in-situ stress was estimated from the previous stress in the four azimuthal directions. The stress in each azimuthal direction was measured on paired specimens for each depth. The peak value of the applied stress was set at a value between 40 and $60 \mathrm{MPa}$ according to the stiffness of the specimen. The data for the horizontal specimens for Samples 127-794C-1R-1, 99-104 $\mathrm{cm}$, and $127-794 \mathrm{C}-4 \mathrm{R}-1,29-40 \mathrm{~cm}$, are shown in Figure 7. We see that the traces of $(i, j)$ are extremely nonlinear and that many traces bend relatively prominently around two values of applied stress, at about 20 and more than $25 \mathrm{MPa}$.

If the bending points are caused by the horizontal previous stresses, the azimuthal dependence of the stresses at which the bending occurs should be expressed by a sinusoidal function of the azimuth with a period of $180^{\circ}$. We can see that the stresses of the bends at higher stresses depend on the azimuth. For Sample 127-794C-1R-1, 99-104 $\mathrm{cm}$, rather clear bending points are observed in loading and unloading experiments for specimens at $\mathrm{F} 0^{\circ} \mathrm{E}$ and $\mathrm{F} 135^{\circ} \mathrm{E}$ (the direction rotated $135^{\circ}$ clockwise from the normal trend against the split-core surface when it is viewed from the top). Although the bending points for specimens at $\mathrm{F} 45^{\circ} \mathrm{E}$ and $\mathrm{F} 90^{\circ} \mathrm{E}$ are difficult to see, we could identify them by assuming the preceding sinusoidal function. For Sample $127-794 \mathrm{C}-4 \mathrm{R}-1,29-40 \mathrm{~cm}$, we also determined the previous stress magnitudes for each specimen in the same manner.

The magnitudes of previous stress obtained by this procedure are plotted as a function of azimuth in Figure 8 for Samples 127-794C$1 \mathrm{R}-1,99-104 \mathrm{~cm}$, and $127-794 \mathrm{C}-4 \mathrm{R}-1,29-40 \mathrm{~cm}$. The previous stress thus obtained is interpreted as the normal component of the in-situ stress in the direction corresponding to the loading axis of the specimen. The maximum and minimum horizontal stresses at a specific depth are determined from the sinusoidal function of the azimuth with the period of $180^{\circ}$ fitted to the stress azimuth relation by a least-squares method. The fitted curves are shown in the figures. The magnitudes of the maximum and the minimum horizontal stresses 
Viewed from the top

127-794C-1R
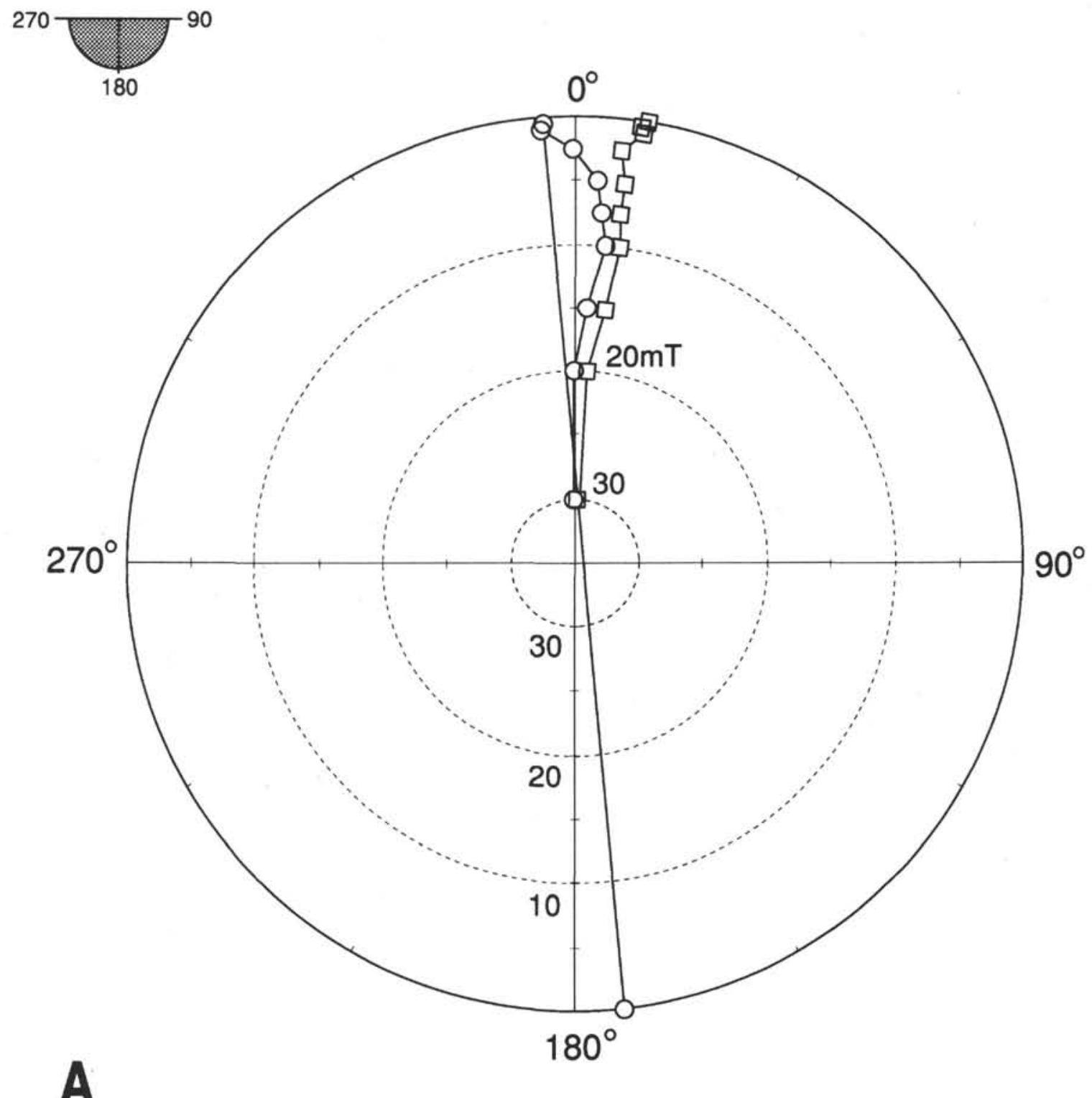

Figure 5. Declination plots of the equi-AF field of each sample taken from the same cut surface. A. Circle: Sample 127-794C-1R-1, 95-97 cm, and square: Sample 127-794C-1R-1, 102-104 cm. The demagnetization zone of 15-20 mT was cited as the most stable paleomagnetism and paleomagnetic north of this sample was determined as F2 ${ }^{\circ}$ E. B. Circle: Sample 127-794C-4R-1, 29-31 cm, and square: Sample 127-794C-4R-1,32-34 cm. The demagnetization zone of 10-20 mT was cited as the most stable paleomagnetism, and paleomagnetic north of this sample was determined as $\mathrm{F} 183^{\circ} \mathrm{E}$.

thus obtained are $(37.3 \pm 0.6,27.4 \pm 0.6)$ and $(39.6 \pm 0.4,27.7 \pm 0.4)$ MPa for Samples 127-794C-1R-1, 99-104 cm, and 127-794C-4R-1, 29-40 cm, respectively, and listed together with the magnitudes of the vertical stresses in Table 3.

The maximum horizontal stress is larger than the vertical stress, and the minimum stress is about $10 \mathrm{MPa}$ less than the maximum one. The average of the largest and the least horizontal stresses is nearly equal to the vertical stress, which means that the site is in the field of the strike slip faults rather than the reverse or the normal faults. If the vertical is assumed to be one of the principal direction of in situ stress, the ratio of the maximum shear stress to the normal one is about 0.16 .

\section{DISCUSSION AND SUMMARY}

We tried to measure the previously applied stresses on basalt samples from Hole $794 \mathrm{C}$ by the DRA method in order to estimate in-situ stress direction and magnitude at the northern end of the Yamato Basin, close to the eastern Japan Sea convergent zone. We expected to evaluate our results by comparison with the results of in-situ stress field measurements by other methods. However, the original attempts during the Leg 127 to measure in-situ stress by the packer-hydrofracturing method and BHTV were defeated by unstable hole conditions. Although the present results have been obtained from 

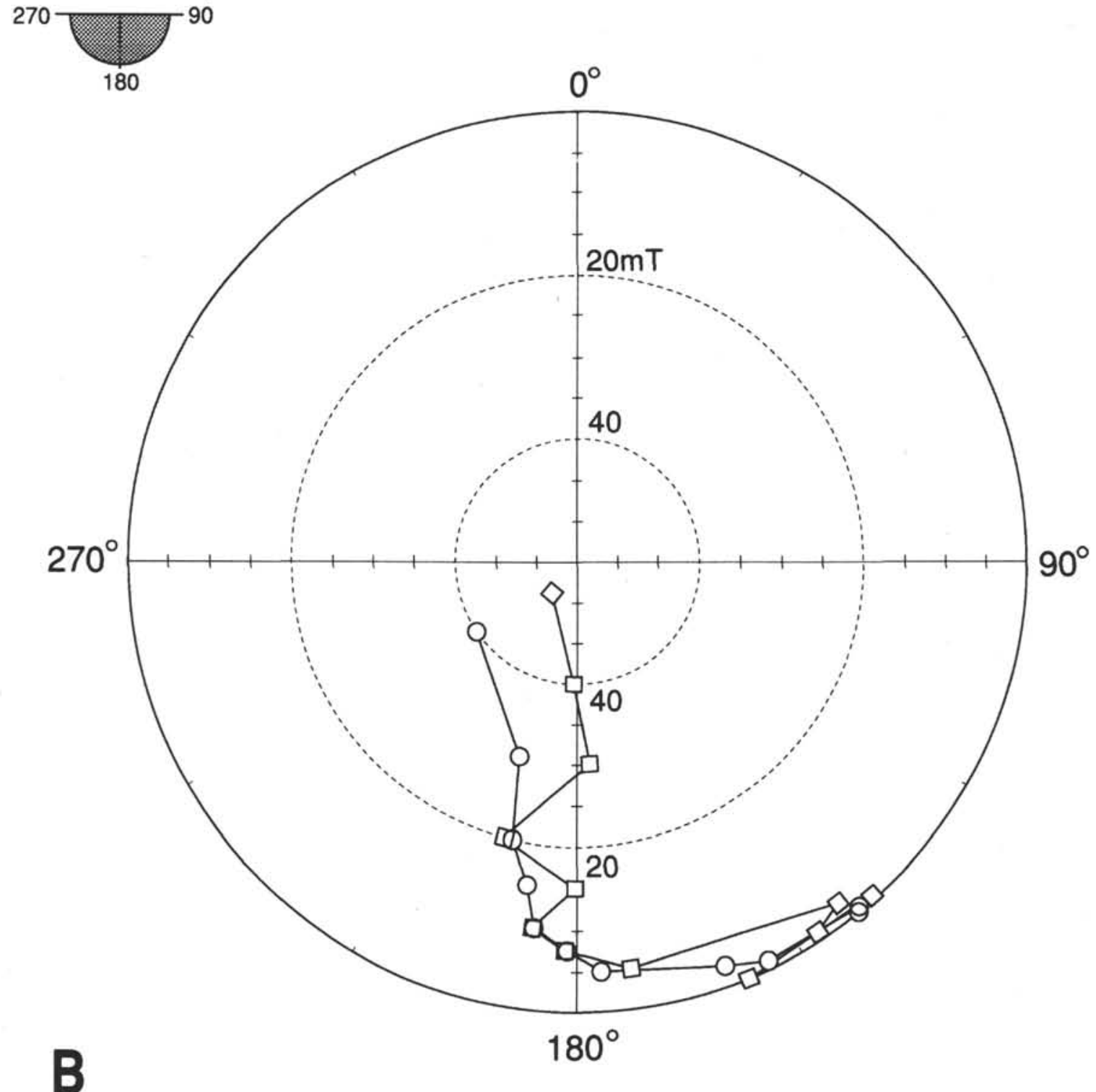

Figure 5 (continued).

the specimens whose strengths of compression are too small to definitely determine the stress values and also include some ambiguities in the stress orientation which are determined by the paleomagnetic measurement, here we discuss our results briefly in relation to the stress field in the area.

Cubic basalt samples recovered from two depths (561 mbsf for Core $127-794 \mathrm{C}-1 \mathrm{R}$ and $582 \mathrm{mbsf}$ for Core $127-794 \mathrm{C}-4 \mathrm{R})$ were measured (Table 3 ). The possible in-situ orientation of the samples was estimated from the declination of the NRM magnetization of each sample with the assumption that the NRM north may not have suffered appreciable shift. The final estimation of the orientation of the in-situ stress is summarized in Table 4. Estimation of vertical stress at $36.4 \mathrm{MPa}$ was done only for the Core $127-794 \mathrm{C}-4 \mathrm{R}$ sample after correction for the pore-pressure effect. As the vertical stress is considered to be one of the principal stress directions, the maximum and minimum principal stresses are in a horizontal plane, and this configuration of the principal stress axes corresponds to the stress field that causes strike-slip faults.

The horizontal stresses of Core 127-794C-1R are 0.3-2.3 MPa larger than that of Core 127-794C-4R. As the 21-m depth difference between two cores corresponds to a difference of $0.5 \mathrm{MPa}$ as a vertical stress, the difference of 0.3-2.3 MPa may not depend merely on the difference in depth. Although we were unable to measure the porosity of the Core 127-794C-1R sample, we can estimate from the difference in Young's moduli between the samples that the porosity of the sample is larger than that of Core $127-794 \mathrm{C}-4 \mathrm{R}$. The porosity difference of $1 \%$ generally corresponds to a difference in stress of about $0.35 \mathrm{MPa}$. We assume that the difference of the magnitudes of the estimated horizontal stresses mainly depends on the difference in the porosity between the two depths. 


\section{7-794C-4R Vertical}

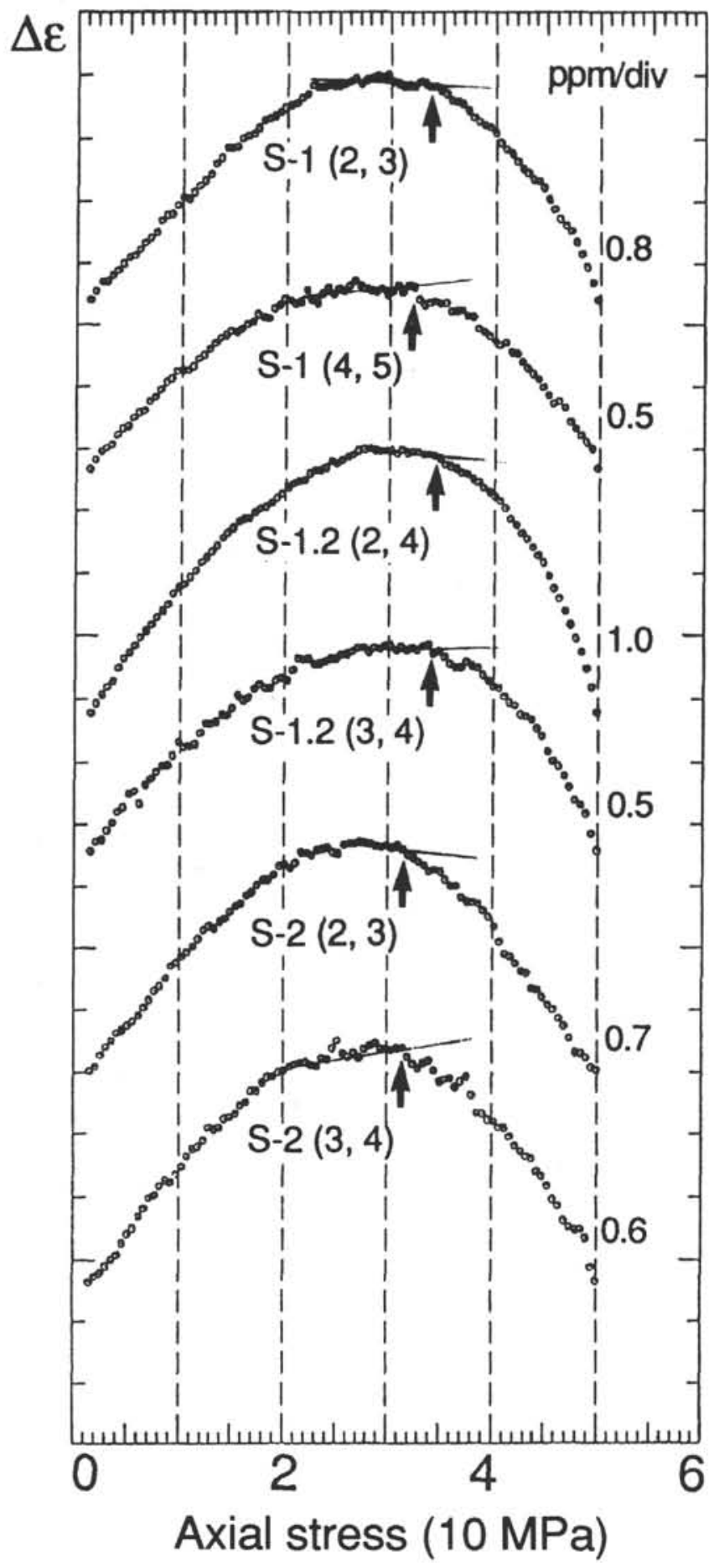

Figure 6. Strain difference functions measured on a vertical sample specimens S-1 and S-2 of Section 127-794C-4R-1. S-1.2 denotes the second measuremen of specimen $\mathrm{S}-1$. The $(\mathrm{i}, \mathrm{j})$ values are a set of $\mathrm{i}^{\text {th }}$ and $\mathrm{j}^{\text {th }}$ loading cycles used for driving the function. The functions for all sets of the successive cycles are shown. The arrow indicates the point at which the value of the axial stress was read as the magnitude of the previously applied stress. The sensitivity of the strain difference is also labeled.
The difference between the maximum and the minimum stresses is about $10 \mathrm{MPa}$, and this value is nearly equal to the one obtained at Hole $758 \mathrm{~A}$ on Ninetyeast Ridge by Tamaki et al. (1991). The obtained ratio of the maximum shear stress to the normal stress, 0.16 , is also close to that of Hole 758A, 0.20. While the vertical stress of Hole 758A is larger than the maximum horizontal stress, the vertical stress of Hole 794C is between the maximum and minimum horizontal stresses. Thus, the difference of stress state between both sites is clearly defined. If we collect more data of this kind at a shallow part of the crust in the ocean basin, we will be able to understand the stress state in the ocean basin more under a variety of different conditions.

Using the azimuthal orientation of each sample obtained from the stable magnetization direction, the maximum principal horizontal stresses are approximately $\mathrm{N} 54^{\circ} \mathrm{E}$ in azimuth in Core $127-794 \mathrm{C}-1 \mathrm{R}$ and approximately $\mathrm{N} 50^{\circ} \mathrm{E}$ in azimuth in Core $127-794 \mathrm{C}-4 \mathrm{R}$. These orientations are against paleomagnetic north. Although the difference between paleomagnetic north and present geomagnetic north is unknown, the coincidence of the measurements suggests that the stress orientation against paleomagnetic north is probably correct. However, there is a possibility that the Site 794 was rotated since the basalts erupted and originally magnetized. Tosha and Hamano (1988) invoked the amount of rotation of the northeast Japan as about $20^{\circ}$ counterclockwise since $22 \mathrm{Ma}$. As the basalts at Site 794 were dated at about $20 \mathrm{Ma}$ by Kaneoka et al. (this volume), taking account of the rotation of the site which may have occurred in accordance with the rotation of the northeast Japan while the Japan Basin was spreading by accretion of oceanic crust, the paleomagnetic north may be between $0^{\circ}$ and about $20^{\circ}$ west from the present north. Thus, the stress orientation is estimated to be between $\mathrm{N} 54^{\circ} \mathrm{E}$ and $\mathrm{N} 34^{\circ} \mathrm{E}$ for the largest horizontal stress and between $\mathrm{N} 36^{\circ} \mathrm{W}$ and $\mathrm{N} 56^{\circ} \mathrm{W}$ for the least one. In conclusion, if we disregard the possibility of local rotation of the site, the trends of the largest and the least horizontal stresses are about northeast and about northwest, respectively.

Yamazaki et al. (1985) summarized the seismogenic stress field at the eastern margin of the Japan Sea. Taking account of the errors in the hypocentral determination, the earthquakes they analyzed may be understood to occur on and close to the convergent boundary around the northern Yamato Basin with one exceptional earthquake which was located near the central part of the Japan Basin (Fig. 9). The stress fields determined from these earthquakes are of the reverse faults, where east-west or northwest-southeast compression is dominant. The stress field estimated in the present study is of strike slip faults rather than of the reverse ones, where not the largest but the least horizontal stress has northwest-southeast trend. This trend is nearly in the spreading direction of the Japan Sea and nearly perpendicular to the convergent axis. Thus, the present result may possibly be explained in terms of the spreading and/or the tensional stress in the bending oceanic crust due to the convergence, if the convergence is existing. For this reason, the discrepancy of the estimated stress field to the seismogenic one may depend mainly on the condition that Site 794 is not in the convergent zone. However, we do not intend to extend the discussions until more stress data are collected, because the present data are not definite.

In the stress estimation by DRA from weak specimens, there is the difficulty that the strain difference functions are contaminated by the inelastic strain which is unrelated to the in-situ stresses. This difficulty will be overcome by making use of a triaxial loading compression on specimens, that is, by loading specimens under confining pressure. We need thus to develop the techniques to measure strains with a high resolution under the triaxial compression condition.

\section{ACKNOWLEDGMENTS}

The authors thank Yozo Hamano for discussion and two anonymous reviewers for their valuable comments. The authors also thank Akemi Hatanaka for her paleomagnetic measurements work. 


\section{REFERENCES}

Awata, Y., and Kakimi, K., 1985. Quaternary tectonics and damaging earthquakes in northeastern Honshu, Japan. Japan Earthq. Predict. Res., 3:231-251.

Brace, W. F., Paulding, B. W., Jr., and Scholtz, C. H., 1966. Dilatancy in the fracture of crystalline rocks, J. Geophys. Res., 71:3939-3953.

Fukao, Y., and Furumoto, M., 1975. Mechanism of large earthquakes along the eastern margin of the Japan Sea. Tectonophysics, 25: 7-266.

Ingle, J. C., Jr., Suyehiro, K., von Breymann, M. T., et al., 1990. Proc. ODP, Init. Reports, 128: College Station, TX (Ocean Drilling Program).

Kanagawa, T., Hayashi, M., and Nakasa, H., 1977. Estimation of spatial geo-stress components in rock samples using the Keiser effect of acoustic emission. Proc. Jpn. Soc. Civ. Eng., 258:63-75. (In Japanese)

McGarr, A., and Gay, N. C., 1978. State of stress in the earth's crust. Annu. Rev. Earth Planet. Sci., 6:405-436.

Newmark, R. L., Zoback, M. D., and Anderson, R. N., 1983. Orientation of in situ stresses near the Costa Rica Rift and Peru-Chile Trench: Deep Sea Drilling Project Hole 504B. In Anderson, R. N., Honnorez, J., Becker, K., et al., Init. Repts. DSDP, 83: Washington (U.S. Govt. Printing Office), 511-514.

Siegfried, R., and Simmons, G., 1978. Characterization of oriented cracks with differential strain analysis. J. Geophys. Res., 83:1269-1278.

Simmons, G., Siegfried, R. W., II, and Feves, M., 1974. Differential strain analysis: new method for examining cracks in rocks. J. Geophys. Res., 79:4383-4385.

Tamaki, K., and Honza, E., 1985. Incipient subduction and obduction along the eastern margin of the Japan Sea. Tectonophysics, 119:381-406.

Tamaki, K., Pisciotto, K., Allan, J., et al., 1990. Proc. ODP, Init. Reports, 127: College Station, TX (Ocean Drilling Program).

Tamaki, K., Yamamoto, K., Furuta, T., and Yamamoto, H., 1991. An experiment of in-situ stress estimation on basaltic rock samples from ODP Hole 758A, Ninetyeast Ridge, Indian Ocean. In Peirce, J., Weissel, J., et al.,
Proc. ODP, Sci. Results, 121: College Station, TX (Ocean Drilling Program), 697-717.

Tosha, T., and Hamano, Y., 1988. Paleomagnetism of Tertiary rocks from the Oga Peninsula and the rotation of northeastern Japan. Tectonics, 7:653-662.

Walsh, J. B., 1965. The effect of cracks on the compressibility of rock. $J$. Geophys. Res., 70:381-389,

Yamamoto, K., Kato, N., and Hirasawa, T., 1989. An interpretation of the previously applied stress obtained by deformation rate analysis-depth dependence of the vertical stress. Prog. Abst. Seism. Soc. Jpn., 1989, 1:44. (Abstract in Japanese)

Yamamoto, K., Kuwahara, Y., and Hirasawa, T., 1983. Discrimination of previously applied stress by the deformation rate analysis: application of the method to estimation of in situ stress. Prog. Abst. Seism. Soc. Jpn., 1983, 2:104. (Abstract in Japanese)

Yamamoto, K., Kuwahara, Y., Kato, N., and Hirasawa, T., 1990. Deformation rate analysis: a new method for in situ stress estimation from inelastic deformation of rock samples under uni-axial compressions. Tohoku Geophys. J., 33:127-147.

Yamazaki, K., Tamura, T., and Kawasaki, 1., 1985. Seismogenic stress field of the Japan Sea as derived from shallow and small earthquakes. J. Seismol. Soc. Jpn., 38:541-558.

Zheng, Z., Kemeny, J., and Cook, N.G.W., 1989. Analysis of borehole breakouts. J. Geophys. Res., 94:7171-7182.

Zoback, M. D., and Byerlee, J. D., 1975. The effect of cyclic differential stress on dilatancy in Westerly granite under uniaxial and triaxial conditions. $J$. Geophys. Res., 80:1526-1530.

Zoback, M. D., Moos, D., Mastin, L., and Anderson, R. N., 1985. Wellbore breakouts and in situ stress. J. Geophys. Res., 90:5523-5530.

Date of initial receipt: 7 May 1991

Date of acceptance: 18 September 1991

Ms 127/128B-225 

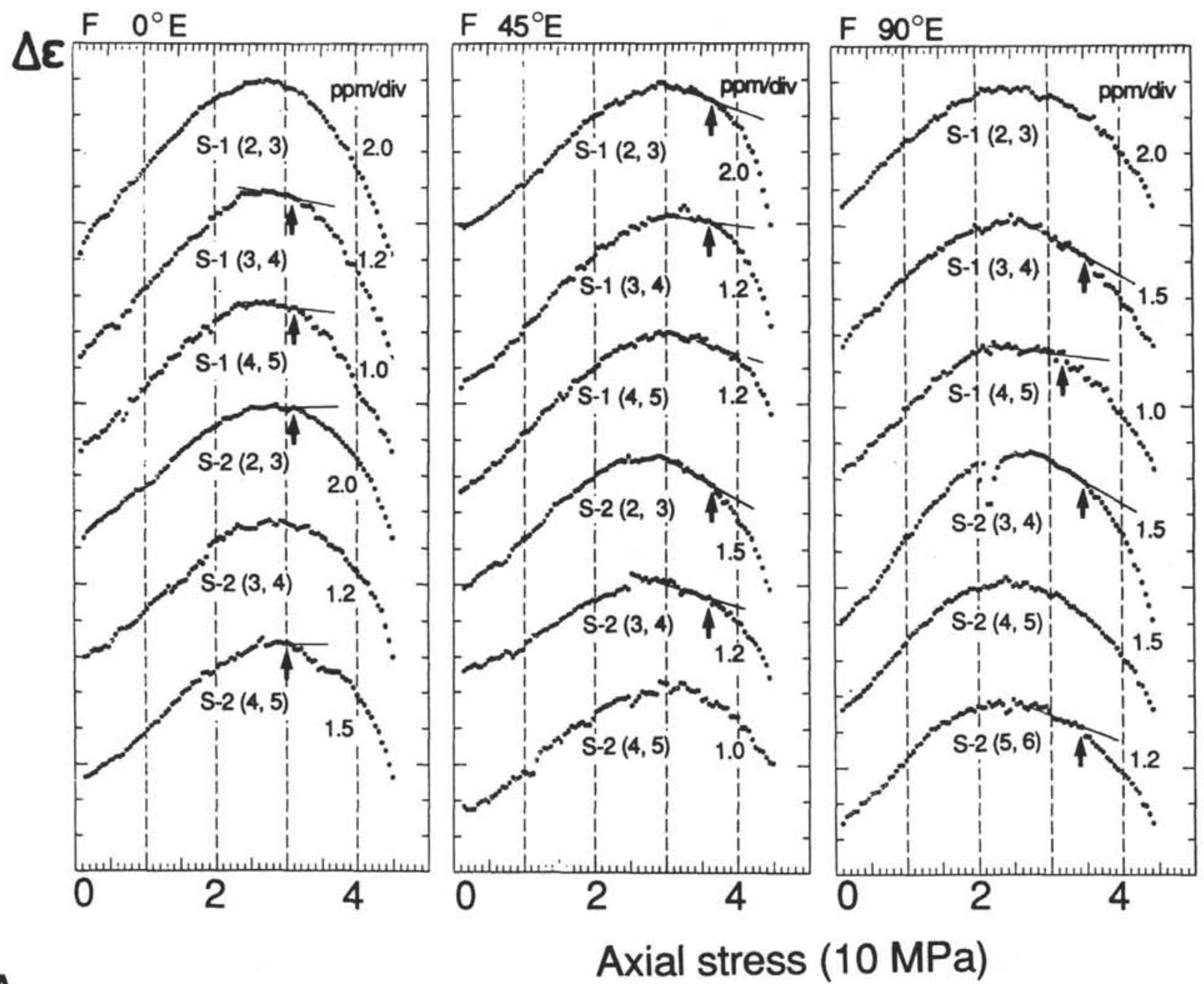

\section{$\mathrm{F} 135^{\circ} \mathrm{E}$}

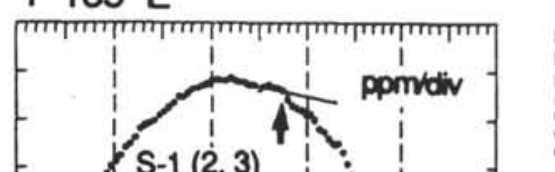

A

Axial stress (10 MPa)

Figure 7. Strain difference functions measured on the horizontal samples of Samples 127-794C-1R-1, 99-104 cm (A), and 127-794C-4R-1, 29-40 cm (B). The functions for the same azimuth are shown in each column, with azimuth indicated at the top of each column. F corresponds to the direction normal to the split core surface and E denotes the clockwise direction. The symbols are the same as those in Figure 6. 


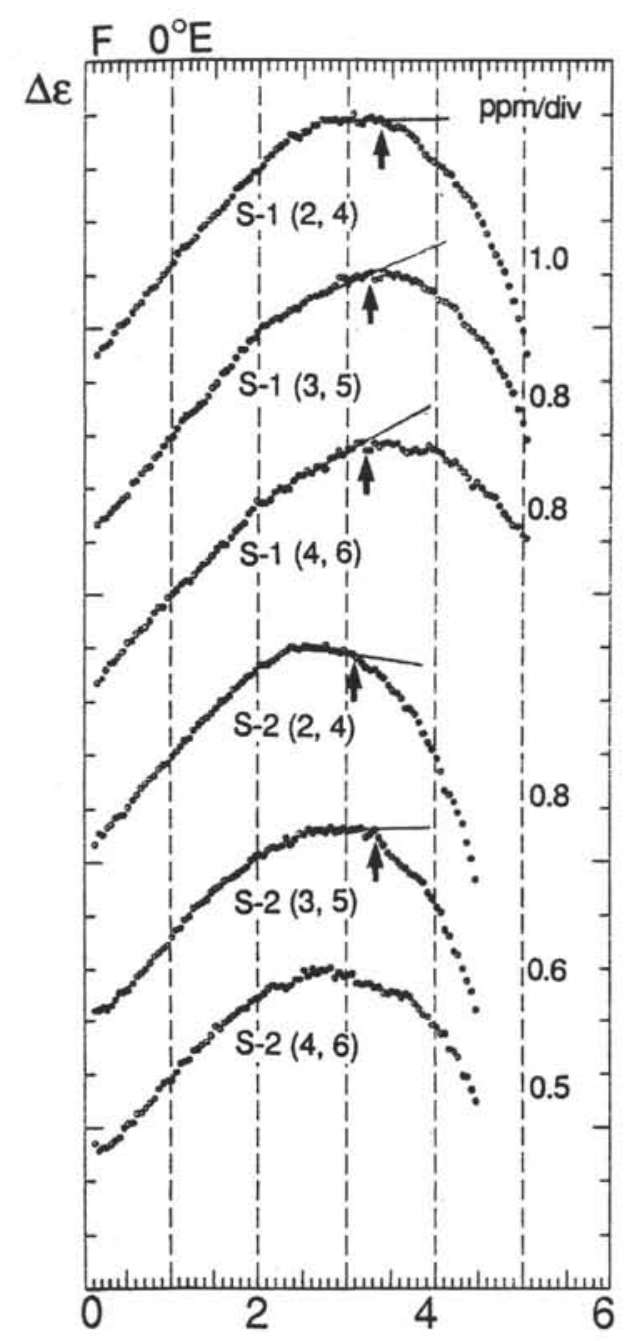

$\mathrm{F} 45^{\circ} \mathrm{E}$

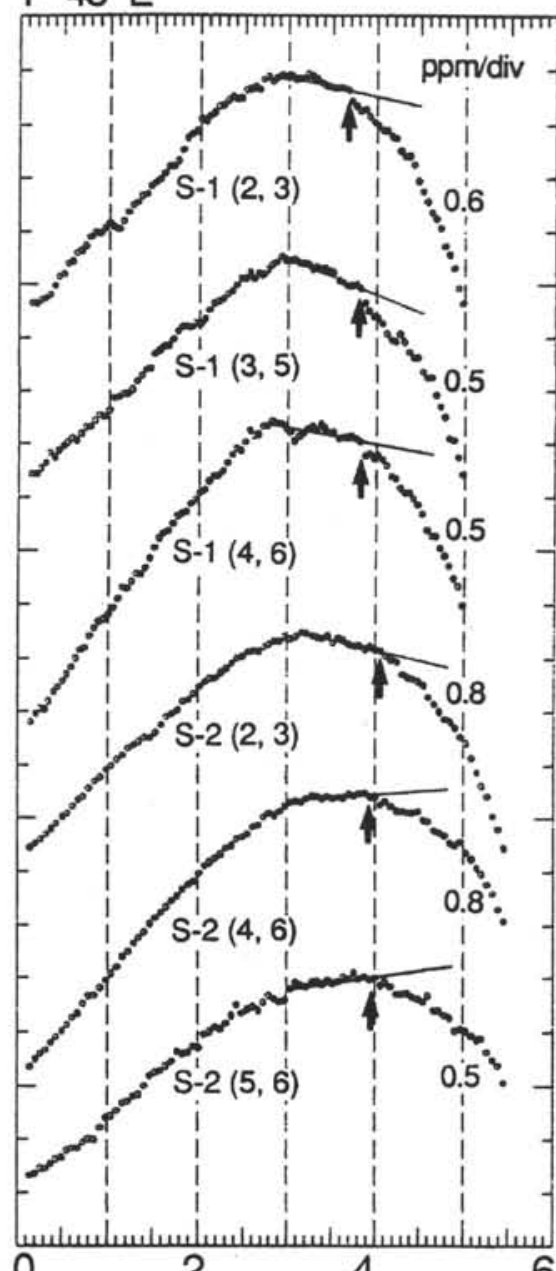

(F $\mathrm{F} 90^{\circ} \mathrm{E}$
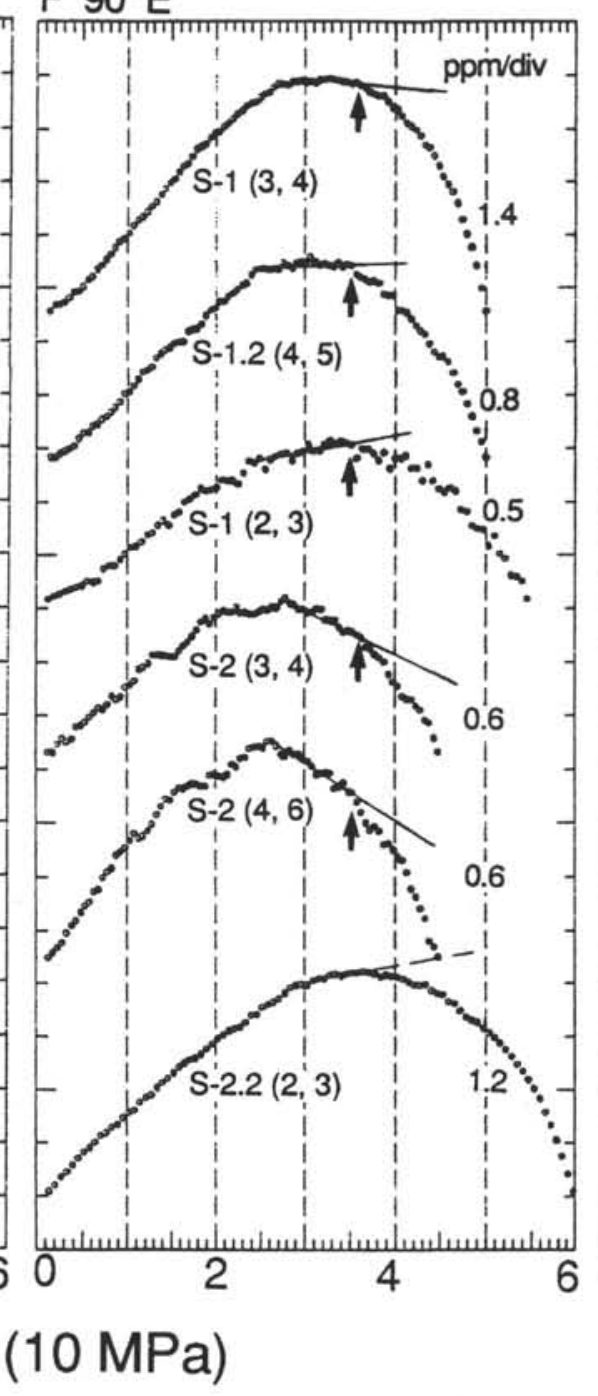

$\mathrm{F} 135^{\circ} \mathrm{E}$

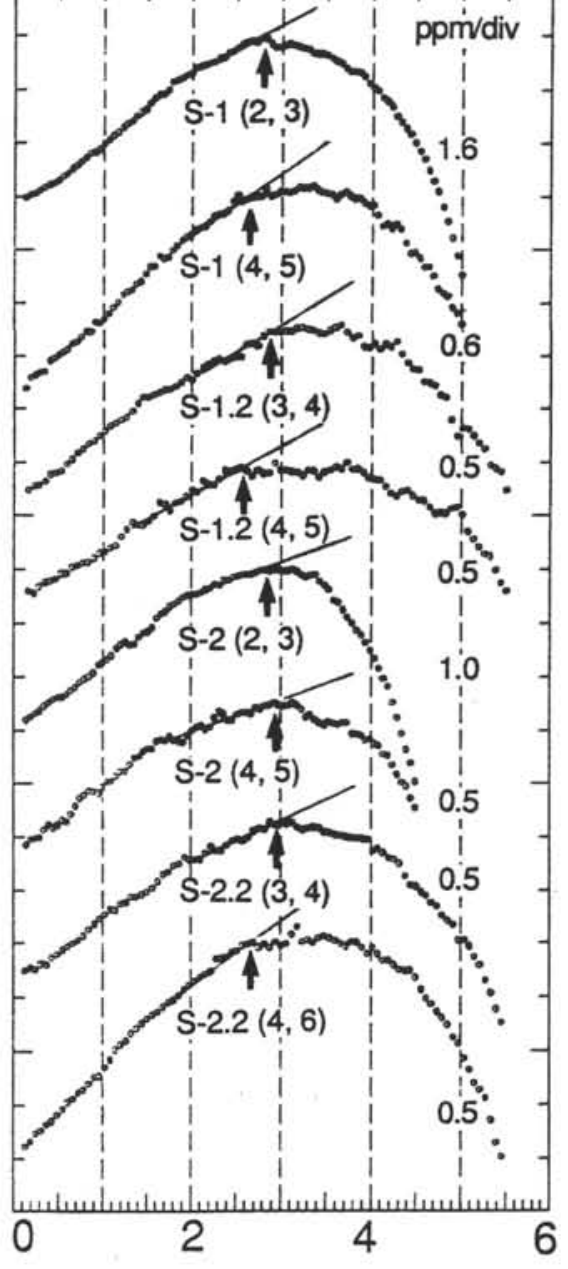

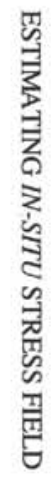

\section{Axial stress (10 MPa)}

B 
A

127-794C-1R

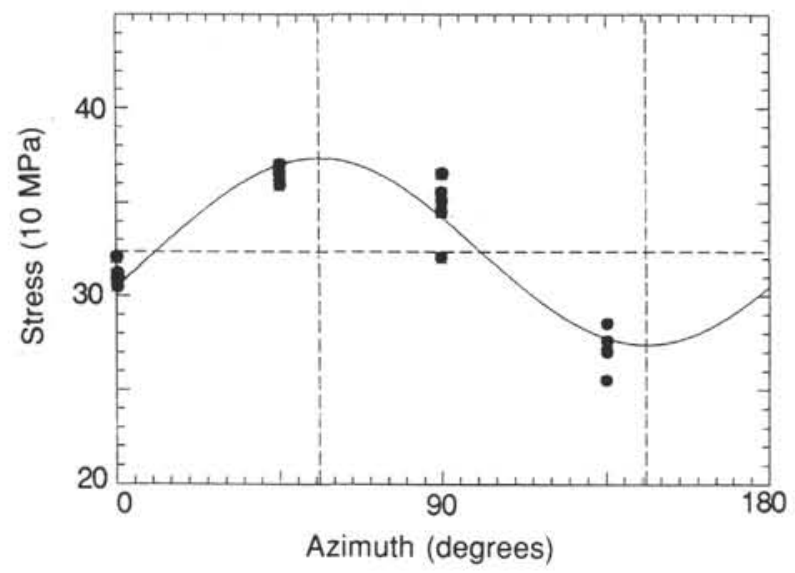

B

$127-794 C-4 R$

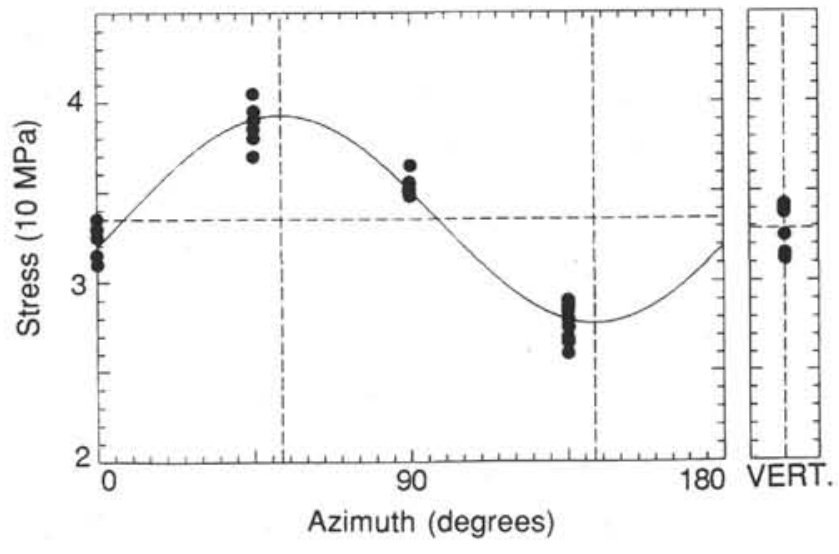

Figure 8. Azimuthal distribution of the previously applied stresses. The azimuth is measured clockwise from the F direction (vertical to the split surface). The line shows the sinusoidal function fitted to the data by the least-squares method. A. Sample $127-794 \mathrm{C}-1 \mathrm{R}-1,99-104 \mathrm{~cm}$. B. Sample $127-794 \mathrm{C}-4 \mathrm{R}-1,29-40 \mathrm{~cm}$. The data for vertical direction are plotted to the right.

Table 3. Correction of previously applied stress for the pore-pressure effect.

\begin{tabular}{|c|c|c|c|c|c|c|c|}
\hline \multirow[b]{2}{*}{ Sample } & \multicolumn{3}{|c|}{ Previously applied stress } & \multirow[b]{2}{*}{$\begin{array}{l}\text { Correction for pore- } \\
\text { pressure effect } \\
(\mathrm{MPa})\end{array}$} & \multicolumn{3}{|c|}{ Corrected previously applied stress } \\
\hline & $\begin{array}{c}\text { Vertical stress } \\
\text { (MPa) }\end{array}$ & $\begin{array}{c}\text { Maximum } \\
\text { horizontal stress } \\
(\mathrm{MPa})\end{array}$ & $\begin{array}{c}\text { Minimum } \\
\text { horizontal stress } \\
(\mathrm{MPa})\end{array}$ & & $\begin{array}{l}\text { Vertical stress } \\
\quad(\mathrm{MPa})\end{array}$ & $\begin{array}{c}\text { Maximum } \\
\text { horizontal stress } \\
(\mathrm{MPa})\end{array}$ & $\begin{array}{c}\text { Minimum } \\
\text { horizontal stress } \\
(\mathrm{MPa})\end{array}$ \\
\hline 127-794C-1R-1 & & $37.3 \pm 0.6$ & $27.4 \pm 0.6$ & & & & \\
\hline $127-794 \mathrm{C}-4 \mathrm{R}-1$ & $32.9 \pm 1.3$ & $39.6 \pm 0.4$ & $27.7 \pm 0.4$ & 3.5 & 36.4 & 43.1 & 31.2 \\
\hline
\end{tabular}

Table 4. Previously applied stresses and geomagnetic NRM.

\begin{tabular}{|c|c|c|c|c|c|c|c|}
\hline \multirow[b]{2}{*}{ Sample } & \multicolumn{3}{|c|}{ Estimated in-situ stress } & \multirow{2}{*}{$\begin{array}{l}\text { Apparent direction } \\
\text { of maximum } \\
\text { horizontal stress } \\
\text { (degrees) }\end{array}$} & \multicolumn{2}{|c|}{ Geomagnetic NRM } & \multirow{2}{*}{$\begin{array}{c}\text { Estimated } \\
\text { orientation of maximum } \\
\text { horizontal stress against the } \\
\text { paleomagnetic north } \\
\text { (degrees) }\end{array}$} \\
\hline & $\begin{array}{c}\text { Vertical stress } \\
(\mathrm{MPa})\end{array}$ & $\begin{array}{c}\text { Maximum } \\
\text { horizontal stress } \\
(\mathrm{MPa})\end{array}$ & $\begin{array}{c}\text { Minimum } \\
\text { horizontal stress } \\
(\mathrm{MPa})\end{array}$ & & $\begin{array}{c}\text { Incli- } \\
\text { nation } \\
\text { (degrees) }\end{array}$ & $\begin{array}{c}\text { Decli- } \\
\text { nation } \\
\text { (degrees) }\end{array}$ & \\
\hline $127-794 \mathrm{C}-1 \mathrm{R}-1$ & & & & F55.9 $\pm 2.6 \mathrm{E}$ & -36 & 2 & N54E \\
\hline $127-794 C-4 R-1$ & 36.4 & 43.1 & 31.2 & $\mathrm{~F} 53.3 \pm 1.4 \mathrm{E}$ & -33 & 183 & N50E \\
\hline
\end{tabular}




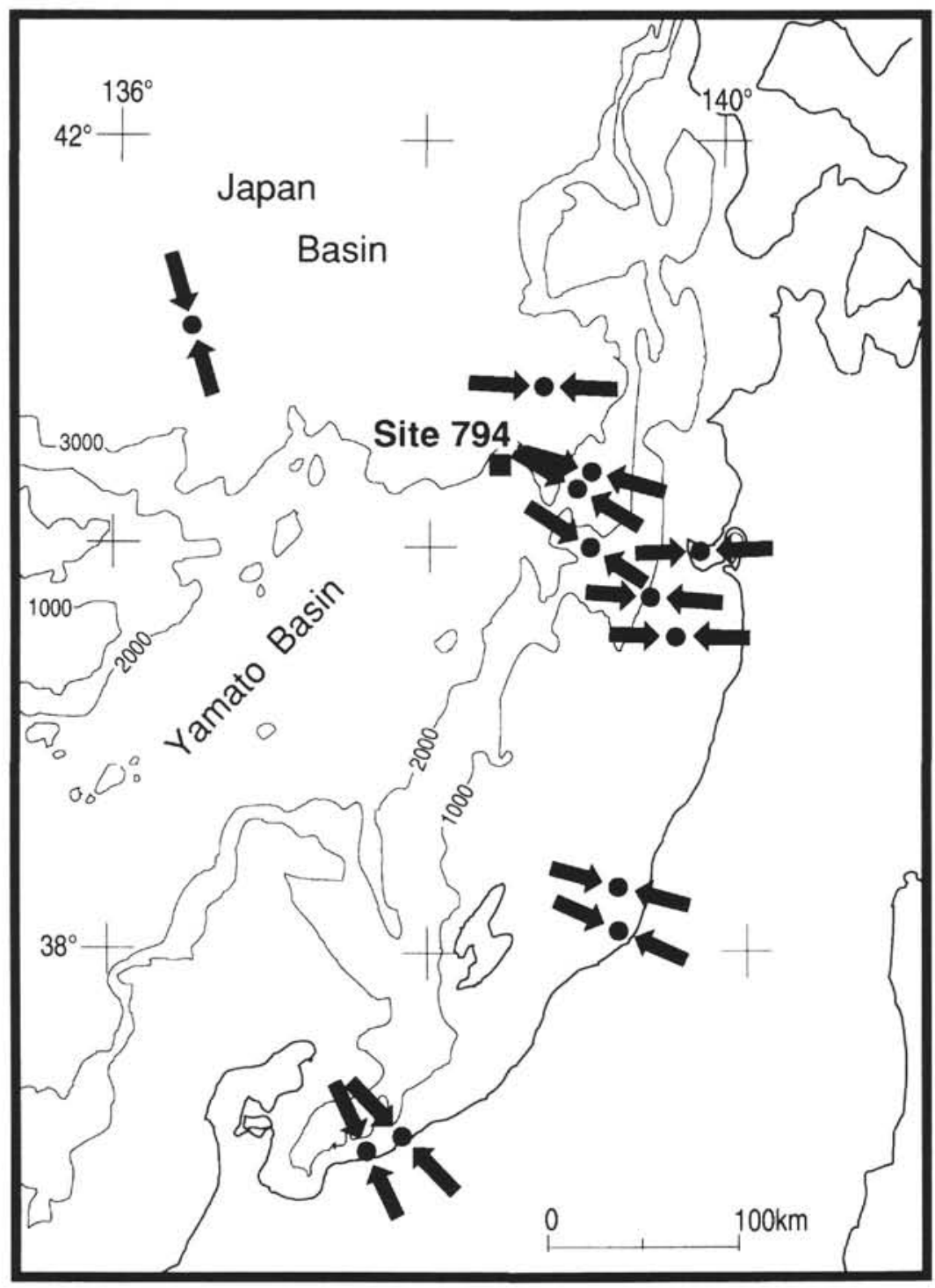

Figure 9. Distribution of seismogenic maximum compression axes in the eastern Japan Sea (Yamazaki et al., 1985). 